\title{
Peroxisome proliferator-activated receptors in reproductive tissues: from gametogenesis to parturition
}

\author{
P Froment, F Gizard ${ }^{1}$, D Defever ${ }^{2}$, B Staels ${ }^{1}$, J Dupont ${ }^{3}$ \\ and $\mathbf{P}$ Monget $^{3}$
}

INSERM U.418, UMR Communications Cellulaire et Différenciation, Hôpital Debrousse, 29 rue Soeur Bouvier, 69322 Lyon, France

${ }^{1}$ INSERM U.545, Institut Pasteur de Lille et Faculté de Pharmacie Université de Lille 2, 1 rue du Pr Calmette, 59019 Lille, France

${ }^{2}$ LMCB, Department of Molecular Biomedical Research, V.I.B., Technologiepark 927, B-9052 Ghent (Zwijnaarde), Belgium

${ }^{3}$ Physiologie de la reproduction et des comportements, UMR 6175 INRA-CNRS-Université F. Rabelais de Tours-Haras Nationaux, 37380 Nouzilly, France

(Requests for offprints should be addressed to P Froment; froment@lyon.inserm.fr)

\begin{abstract}
Peroxisome proliferator-activated receptors $(\operatorname{PPAR} \alpha$, $\operatorname{PPAR} \beta / \delta$ and $\operatorname{PPAR} \gamma$ ) are a family of nuclear receptors that are activated by binding of natural ligands, such as polyunsaturated fatty acids or by synthetic ligands. Synthetic molecules of the glitazone family, which bind to $\operatorname{PPAR} \gamma$, are currently used to treat type II diabetes and also to attenuate the secondary clinical symptoms frequently associated with insulin resistance, including polycystic ovary syndrome (PCOS). PPARs are expressed in different compartments of the reproductive system (hypothalamus, pituitary, ovary, uterus and testis). Conservative functions of PPARs in mammalian species could be suggested through several in vivo and in vitro studies, especially in the ovary and during placental development. Several groups have described a strong expression of PPAR $\gamma$ in ovarian granulosa cells, and glitazones modulate
\end{abstract}

granulosa cell proliferation and steroidogenesis in vitro. All these recent data raise new questions about the biologic actions of PPARs in reproduction and their use in therapeutic treatments of fertility troubles such as PCOS or endometriosis. In this review, we first describe the roles of PPARs in different compartments of the reproductive axis (from male and female gametogenesis to parturition), with a focus on PPAR $\gamma$. Secondly, we discuss the possible molecular mechanisms underlying the effect of glitazones on PCOS. Like other 'insulin sensitizer' molecules, such as metformin, glitazones may in fact act directly on ovarian cells. Finally, we discuss the eventual actions of PPARs as mediators of environmental toxic substances for reproductive function.

Journal of Endocrinology (2006) 189, 199-209

\section{Introduction}

$\operatorname{PPAR} \gamma$ is a nuclear receptor of the peroxisome proliferatoractivated receptor family, which also includes PPAR $\alpha$ and $\mathrm{PPAR} \beta / \delta$ (for review, see Sorensen et al. 1998, Desvergne \& Wahli 1999). PPAR $\gamma$ is activated after the binding of natural ligands such as polyunsaturated fatty acids and prostaglandin metabolites. It can also be activated by synthetic ligands such as thiazolidinediones (TZDs), also known as glitazones (rosiglitazone, pioglitazone or troglitazone) (Lehmann et al. 1995). The binding of TZDs to their receptors increases insulin sensitivity, and most bind primarily to PPAR $\gamma$ in adipose cells. TZDs are frequently administered to patients with insulin resistance associated with type II diabetes (for review, see Houseknecht et al. 2002, Gurnell et al. 2003, Staels \& Fruchart 2005).
Since the discovery of PPARs in 1990 (Issemann \& Green 1990), numerous functions have been attributed to these receptors. In addition to enhancing insulin sensitivity, PPAR $\gamma$ has been shown to regulate fat mass and cell proliferation (Debril et al. 2001) and to modulate inflammatory reactions. Three PPAR isoforms are expressed in the central nervous system and in the following reproductive tissues: gonads (ovary, testis), uterus, prostate, mammary gland and pituitary gland (Komar et al. 2001, Froment et al. 2003, Mouihate et al. 2004).

Fuel sensors, such as glucose, insulin or leptin, are known to be directly involved in the regulation of fertility at each level of the hypothalamo-pituitary-gonad axis (for review, see Poretsky et al. 1999, Froment et al. 2001). For example, mice lacking insulin-signaling pathway components, such as insulin receptor substrate 2 (IRS-2) 
or insulin receptor, exhibit female and male infertility (Bruning et al. 2000, Burks et al. 2000). PPAR $\gamma$ activation modifies the transcription and/or activity of different key regulators of energy homeostasis (Devergne \& Wahli 1999), for example stimulation of several glucose regulators (glucose transporters, insulin receptor, IRS, etc.) (for review, see Picard \& Auwerx 2002). We can hypothesize that PPAR $\gamma$ acts also as a fuel sensor in reproductive compartments to inform cells on the energy status. In this case, PPAR $\gamma$ may be a link between energy metabolism and reproduction, as in polycystic ovary syndrome (PCOS), which is frequently associated with insulin resistance.

\section{Expression and putative roles of PPARs in reproductive tissues}

\section{Hypothalamic-pituitary axis}

In the last 3 years, several teams have demonstrated PPAR $\gamma$ expression in the pituitary gland (mouse and sheep) (Heaney et al. 2003, Mouihate et al. 2004) and in the hypothalamus (rat) (Mouihate et al. 2004). PPAR $\gamma$ has antiproliferative effects in pituitary cells (Heaney et al. 2003), and the administration of TZDs inhibits the development of pituitary adenomas in mice and man. Moreover, PPAR $\gamma$ expression in the pituitary gland may decrease by about $54 \%$ after $24 \mathrm{~h}$ of restricted food intake (Wiesner et al. 2004).

In the human hypothalamus, PPAR $\gamma$ may play a role in temperature regulation, as its natural ligand is 15d-PGJ2 (15-deoxy-delta12,14-prostaglandin $\mathrm{J}_{2}$ ), which is secreted into the cerebrospinal fluid (Mouihate et al. 2004). Despite its presence in these organs, PPAR $\gamma$ does not seem to affect reproductive function at this level of signaling. Indeed, in vitro, the secretion of ovine pituitary hormones, including PRL (prolactin), GH (growth hormone), FSH (follicle-stimulating hormone) and LH (luteinizing hormone), and $\mathrm{LH}$ secretion by murine LbetaT2 gonadotropic pituitary tumor cells do not seem to be affected by TZD treatment (Froment et al. 2003).

\section{Testis}

In the testis, the three PPAR isoforms are expressed in both somatic and germ cells (Braissant et al. 1996, Elbrecht et al. 1996, Bhattacharya et al. 2005). PPAR $\alpha$ and $\operatorname{PPAR} \beta / \delta$ are widely expressed in interstitial Leydig cells and seminiferous tubule cells (Sertoli and germ cells) (Braissant et al. 1996, Schultz et al. 1999). On the other hand, PPAR $\gamma$ is thought to be restricted to Sertoli cells (Elbrecht et al. 1996, Corton \& Lapinskas 2005). However, Thomas et al. (2005) recently detected PPAR $\gamma$ mRNA in germ cells (spermatocytes) (Fig. 1d). The action of PPARs in the testis is unclear, but these receptors do not seem to play an important role in fertility. Indeed, PPAR $\alpha$ - and PPAR $\beta / \delta$-null mice are viable and fertile (Lee et al. 1995, Peters et al. 2000). Xenobiotic ligands of $\operatorname{PPAR} \gamma$ and PPAR $\alpha$ induce the translocation of these receptors to the nucleus of Sertoli cells (Bhattacharya et al. 2005). PPAR $\gamma$ is also more strongly expressed in human testicular cancer cells than in normal testicular tissues. PPAR $\gamma$ ligands (TZDs or 15d-PGJ2) have antiproliferative effects on testicular cancer cells (Hase et al. 2002). In addition, the incubation of testicular tissue with TZDs induces a decrease in the level of mRNA for resistin, which impairs insulin sensitivity and glucose tolerance (Nogueiras et al. 2004). The expression of PPAR $\alpha$ is upregulated by FSH (Schultz et al. 1999), a key hormone that also stimulates the production of testicular fluid components, protein synthesis and the mobilization of energy sources. PPAR $\alpha$ may play a physiologic role in steroidogenesis (see below, under heading 'PPARs mediators of endocrine disruptors of environmental origin?') and may influence the fertility of spermatozoa. Indeed, PPAR $\alpha$ regulates the beta-oxidation of lipids and may also regulate the fatty acid composition of phospholipids in germ cells. The lipid composition of spermatozoa is known to modulate their mobility and its viability (Douard et al. 2003).

\section{Ovary}

Expression and localization (Fig. 1a and b) The $\operatorname{PPAR} \alpha$ and PPAR $\beta / \delta$ isoforms are expressed primarily in the theca and stroma tissues. PPAR $\alpha$ deletion has no apparent effect on the fertility of mice, but the deletion of $\operatorname{PPAR} \gamma$ and PPAR $\beta / \delta$ does have this effect (Lee et al. 1995, Peters et al. 2000, Barak et al. 2002). In the ovaries of rodents and ruminants, PPAR $\gamma$ is expressed strongly in the granulosa cells, and less strongly in the theca cells and corpus luteum (Gasic et al. 1998, Komar et al. 2001, Froment et al. 2003). PPAR $\gamma$ is detected early in folliculogenesis, at the primary/secondary follicle stage (Komar 2005). PPAR $\gamma$ expression increases until the large follicle stage (Froment et al. 2003, Komar 2005), and decreases after the LH surge (Komar et al. 2001) (Fig. 1a and b).

PPAR $\gamma$ action on steroidogenesis and proliferation during folliculogenesis Several studies have shown that TZDs present contradictory actions on secretion of steroids (inhibition or stimulation of progesterone and estradiol production) in granulosa cells (Fig. 1c).

Thus, TZDs stimulate in vitro the secretion of steroids (progesterone and estradiol) by rat and ovine granulosa cells (Komar et al. 2001, Froment et al. 2003), bovine lutein cells (theca- and granulosa-derived cells) (Lohrke et al. 1998) and porcine theca cells (Schoppee et al. 2002), whereas they inhibit the secretion of progesterone and 

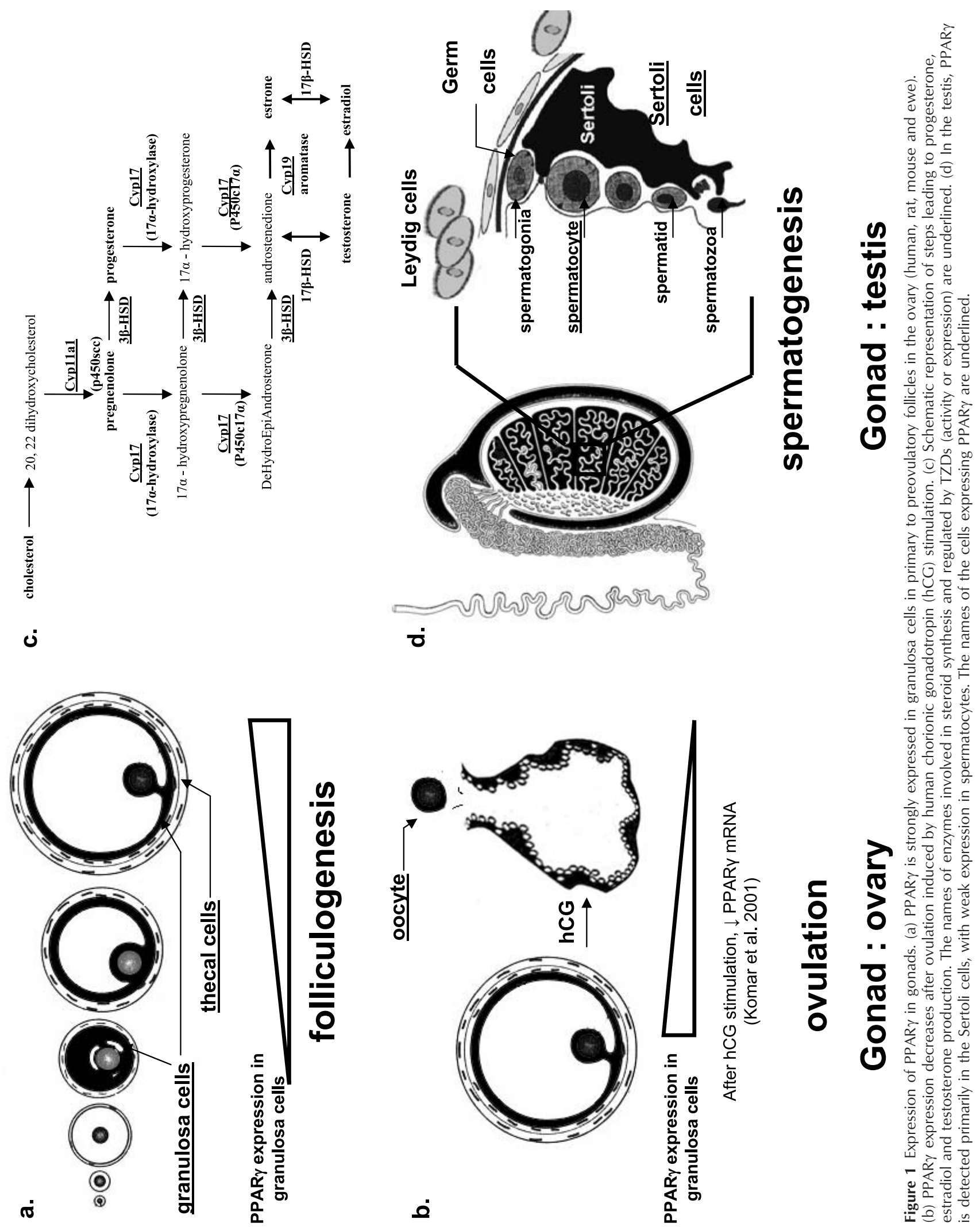

흔 응믐 
estradiol by porcine granulosa cells and by human granulosa cells from patients who underwent in vitro fertilization (Gasic et al. 1998, Mu et al. 2000).

The species and the status of the granulosa cell differentiation (follicular phase, before or after the gonadotropin surge) could modulate these actions of TZDs on steroidogenesis. For example, TZDs stimulated progesterone secretion by a mixture of granulosa, theca and stroma human cells obtained from premenopausal/perimenopausal patients without gonadotropin treatment at the time of oophorectomy (Seto-Young et al. 2005). However, TZDs inhibited progesterone secretion by human granulosa cells obtained from adult women who underwent in vitro fertilization, as stated above (after equine (e) chorionic gonadotropin (CG) and human (h)CG stimulation), or by luteal-granulosa cells obtained from PCOS patients.

These actions of TZDs probably induce more an effect on the activity of steroidogenic enzymes (3-betahydroxysteroid-dehydrogenase (3- $\beta$ HSD) and aromatase) than a direct effect of PPAR $\gamma$ activation on the promoters of the genes encoding these enzymes (Gasic et al. 1998, 2001, Mu et al. 2000). Indeed, Gasic et al. (1998) reported that TZDs 'did not affect messenger RNA concentrations of Cyp11a1 and 3-BHSD by using standard Northern methodology'. On the other hand, in media from porcine granulosa cells, TZD treatment increased the release of pregnenolone, a precursor of progesterone and substrate of $3 \beta-\mathrm{HSD}$, whereas it decreased the release of progesterone. These results suggest that TZDs decrease the activity of the $3 \beta-H S D$ enzyme. Moreover, no effect on the amount of Cyp11a1 and $3-\beta H S D$ proteins in ovine granulosa cells (Froment et al. 2003) or of CYP17 protein in porcine theca cells (Shoppee et al. 2002) was observed after TZDs treatment. However, in human, granulosa-like tumor KGN cells, the activation of PPAR $\gamma$ was recently shown to downregulate aromatase gene expression via the NF- $\kappa B$ pathway (Fan et al. 2005).

In addition to the effects of PPAR $\gamma$ binding on steroid secretion, TZDs decreased the proliferation of sheep granulosa cells (Froment et al. 2003), and the viability of rat granulosa cells (Lovekamp-Swan \& Chaffin 2005), in association with an increase in the expression and/or stabilization of tumor suppressor p53 (Lovekamp-Swan \& Chaffin 2005). However, in vivo, PPAR $\gamma$ expression was not found to be correlated with the atresia status of follicles (atresia is a process leading to follicular growth arrest, mediated by apoptosis) (Komar et al. 2001, Froment et al. 2003).

PPAR $\gamma$ action in corpus luteum In cattle, the expression of PPAR $\gamma$ in corpus luteum increases after ovulation. However, if no fertilization or embryo implantation occurs, the corpus luteum regresses and PPAR $\gamma$ expression decreases (Lohrke et al. 1998, Viergutz et al. 2000) (Fig. 2). In chickens, a similar correlation was observed between the onset of egg laying, and the increase in PPAR $\gamma$ levels in the ovaries (Sato et al. 2004). In mice, the tissue-specific deletion of PPAR $\gamma$ in the ovaries, epithelial cells and lymphocytes leads to a decrease in fertility (Cui et al. 2002). This decrease is not due to changes in ovarian folliculogenesis or ovulation rate. Instead, it results from a decrease in the number of embryos implanted, and this, in turn, probably results from a decrease in progesterone secretion by the corpus luteum (Cui et al. 2002). Furthermore, 4 weeks of ciglitazone injection in rats did not modify folliculogenesis, but did increase serum progesterone concentration (Lebovic et al. 2004). Thus, PPAR $\gamma$ seems to play a significant role in fertility control. In particular, this receptor could be responsible for preserving corpus luteum function (i.e. progesterone production to support implantation and gestation) during pregnancy in various species.

Possible molecular mechanisms Molecular mechanisms of PPARs in ovarian functions are not fully understood. Comparisons with other cell models suggest that PPAR $\gamma$ may regulate the expression of genes required for follicular development, ovulation, oocyte maturation and maintenance of the corpus luteum. For example, the genes encoding cyclooxygenase-2 (COX-2) and nitric oxide synthase (NOS) are implicated in ovulation and oocyte meiotic maturation, as attested by the invalidation of these genes in mice (Lim et al. 1997, Jablonka-Shariff et al. 1999). PPAR $\gamma$ downregulates COX-2 and NOS in human cardiac myocytes and in human prostate cells (COX-2) (Mendez \& LaPointe 2003). Interestingly, LH surge downregulated expression of PPAR $\gamma$ in granulosa cells and PPAR $\gamma$ and PPAR $\alpha$ in ovarian macrophage cells. TZD treatment decreased expression of iNOS (inducible NOS) in ovarian macrophage cells (Minge et al. 2006). We can speculate that the diminution of PPAR $\gamma$ expression after LH preovulatory surge (Banerjee \& Komar 2006, Minge et al. 2006) may be associated with an increase in NOS and COX-2 activities (i.e. increase in prostaglandin synthesis) prior to ovulation.

In addition, several proteases (matrix metalloprotease-9, plasminogen activator and plasminogen activator inhibitor (Kato et al. 1999, Xin et al. 1999, Shu et al. 2000)), which play a role in the follicular rupture process and help in tissue remodeling (folliculogenesis and corpus luteum formation), are regulated by PPARs.

Moreover, the formation and function of corpus luteum involve angiogenesis, steroidogenesis and secretion of prostaglandins. Several observations described above suggest a potential role of PPAR $\gamma$ in steroidogenesis and prostaglandin production. Other studies suggest that $\operatorname{PPAR} \gamma$ plays a role in angiogenesis, as by regulating vascular endothelial growth factor (VEGF), secreted by lutein cells. VEGF maintains the corpus luteum function during pregnancy (Kaczmarek et al. 2005). Indeed, inhibition of VEGF decreases the degree of vascularization 


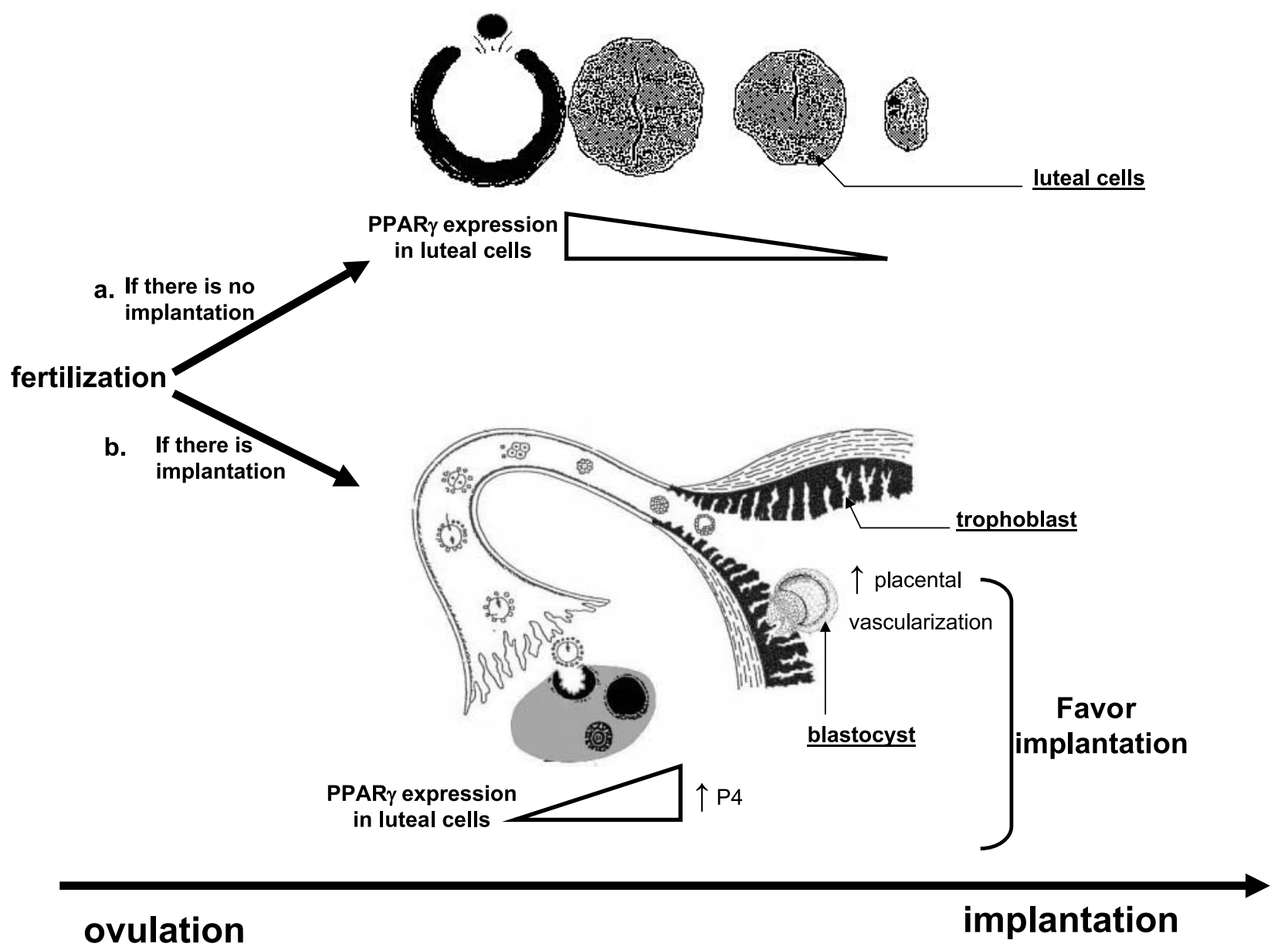

Figure 2 Role of PPAR $\gamma$ in favoring implantation. (a) The corpus luteum expresses PPAR $\gamma$. Note that PPAR $\gamma$ expression decreases in the absence of implantation. (b) PPAR $\gamma$ is expressed in uterine tissue and in the blastocyst. The expression of PPAR $\gamma$ in luteal cells stimulates progesterone secretion, favoring implantation. PPAR $\gamma$ in uterine tissue increases placental vascularization.

and the progesterone secretion by corpus luteum (Fraser et al. 2000). In a human macrophage model and in human vascular smooth muscle cells, PPAR $\gamma$ upregulated VEGF (Bamba et al. 2000, Yamakawa et al. 2000), suggesting that $\operatorname{PPAR} \gamma$ could regulate the function of the corpus luteum (i.e. progesterone secretion) involved in implantation and gestation by several actions.

\section{Do PPARs contribute to pathologic subfertility?}

Link between polycystic ovaries and insulin metabolism

The number of patients with insulin resistance has increased over the last decade, and 3-5\% of adults in Occidental countries now have type 2 diabetes. Insulinresistant women present a higher than average risk of developing fertility disorders. One such disorder, polycystic ovary syndrome (PCOS), is the most frequent cause of female infertility, affecting $\sim 5-10 \%$ of adult women (Dunaif 1997). It is associated with insulin resistance in $60 \%$ of cases. This condition is characterized by the formation of cysts in the ovaries, chronic absence of ovulation and clinical signs of hyperandrogenism (Dunaif 1997, Deneux \& Kuttenn 1998). The etiology of this polyfactorial syndrome is unclear, but several endocrine abnormalities, such as increase in insulin and LH levels, have often been observed (Marshall \& Eagleson 1999). In particular, high circulating LH levels with no preovulatory surge may lead to excess androgens and contribute to the formation of cystic follicles, as described in the mouse model (Risma et al. 1995). A second example is provided by dysregulation of the insulin pathway, rendering theca cells hypersensitive to LH and increasing androgen production (Rosenfield 1999). Mutations in the insulin receptor gene associated with insulin resistance have been described in several cases of PCOS (Dunaif 1999, Jonard \& Dewailly 2002). 
The treatment of diabetic PCOS patients with insulin sensitizers of various drug families, such as TZDs, metformin and D-chiro-inositol, increases the fertility of these patients (Dunaif et al. 1996, Nestler et al. 1999, Iuorno \& Nestler 2001, Seli \& Duleba 2004).

Metformin, a biguanide, has been used for the past 40 years as an oral treatment for type 2 diabetes. Its mechanism of action is based on the stimulation of peripheral glucose uptake and the inhibition of gluconeogenesis in the liver. Recent reports indicate that metformin action involves the activation of AMPactivated protein kinase (AMPK), a regulator of energy metabolism involved in fatty acid and cholesterol metabolism (Zhou et al. 2001, Musi et al. 2002). Metformin also decreases Cyp17 activity (P450-17-hydroxylase) (Fig. 1c), and consequently circulating androgen levels and the mean duration of the follicular phase (La Marca et al. 2000). Interestingly, we recently showed that AMPK is expressed in rat ovary. Its activation decreased $3 \beta-H S D$ protein levels and reduced progesterone production in cultured rat granulosa cells (Tosca et al. 2005). As with PPAR $\gamma$, it is difficult to exclude a possible direct action of metformin on the ovary via AMPK in patients treated for PCOS.

TZDs, such as rosiglitazone and pioglitazone, are used to decrease peripheral insulin resistance, and have the same effects as metformin. In women, TZDs decrease circulating androgen and LH levels indirectly by lowering insulin levels, leading to an increase of the rate of ovulation and the number of successful pregnancies. In contrast, no significant change in body-mass index is observed (Dunaif et al. 1996). There is thus a clear connection between ovary function and glucose and insulin metabolism. The molecular mechanisms underlying this link remain to be clarified.

Biologic effects of TZDs in the treatment of polycystic ovaries: a direct or indirect mechanism of action?

As PPAR $\gamma$ is clearly expressed and active in the ovary, the effects of TZD in PCOS may be accounted for by a direct action on theca and granulosa cells. However, this role of $\operatorname{PPAR} \gamma$ remains hypothetical. Indeed, in PCOS, granulosa cells in vivo undergo premature differentiation into luteal cells and display increases in basal sex steroid secretion in vitro (Rosenfield 1999). Thus, we may expect to observe a systematically inhibiting effect of the TZDs on steroid secretion in vitro, but this is clearly not the case (see above, under the heading 'Expression and localization'). General improvements in insulin sensitivity in the periphery may partly account for the effect of TZDs on ovulation, via an unknown mechanism. Several observations described below are in accord with this indirect action of TZDs in the treatment of PCOS.

First, plasma free fatty acid and/or triglyceride concentrations are high in PCOS patients (Holte et al. 1994). Hypothetically, TZDs could redirect the flow of tri- glycerides to adipose tissue, decreasing plasma free fatty acid and triglyceride concentrations. Indeed, $\operatorname{PPAR} \gamma$ is widely recognized as a major regulator of adipocyte differentiation (Duran-Sandoval et al. 2003).

This TZD-induced return to a 'normal metabolic state' may lead to the secretion of normal amounts of $\mathrm{GnRH}$ (gonadotropin-releasing hormone) and, consequently, to normal levels of FSH and LH secretion.

Secondly, two ovary-independent mechanisms can lead to a decrease in androgen levels, and may indirectly improve ovarian function.

1. TZD treatment increases SHBG (steroid hormonebinding globulin) levels in serum, leading to a decrease in free circulating androgen levels (Brettenthaler et al. 2004).

2. In addition, after long-term treatment, TZDs have a specific effect not seen with metformin: an increase in body fat associated with adipose tissue redistribution, with a decrease in visceral abdominal adipose tissue and an increase in subcutaneous adipose tissue (Larsen et al. 2003).

The accumulation of visceral fat deposits has been shown to be associated with high serum androgen concentrations (Bjorntorp 1996). Thus, the decrease in the profound visceral abdominal adipose tissue could help to explain the decrease of testosterone production.

Finally, recent data on insulin-resistant men treated with TZDs support the hypothesis of a regulation of steroid secretion, which is not mainly due to a direct action of TZDs on the gonads. Indeed, in contrast of women, men with type 2 diabetes have low testosterone secretion levels (Pitteloud et al. 2005), and the administration of rosiglitazone or pioglitazone to these patients could induce an increase in testosterone levels (Kapoor et al. 2005, Patel et al. 2005). Interestingly, PPAR $\gamma$ is not detected in Leydig cells (cells producing androgens), suggesting that the modulation of serum testosterone levels is not due to a direct action of PPAR $\gamma$ on the gonad.

\section{PPARs - mediators of endocrine disruptors of environmental origin?}

PPAR family members also bind to xenobiotic ligands, increasing the size and number of peroxisomes (Corton \& Lapinskas 2005). These ligands include industrial chemicals, such as herbicides, oil derivatives and plasticizers, including phthalate esters. Phthalate esters are components of various types of plastic, such as those used to make storage containers, but are also present in perfumes and cosmetics. Many phthalates are toxic in reproductive function. For example, di-(2-ethylhexyl) phthalate (DEHP) causes considerable damage to somatic and germ cells in the testis, leading to a decrease in sperm production and, in some cases, testicular atrophy (Mylchreest et al. 1998). A recent study showed that phthalate esters decrease testosterone secretion (Thompson et al. 2005) and increase the apoptosis of germ cells in rat testis (Bhattacharya et al. 2005). The administration of phthalate 

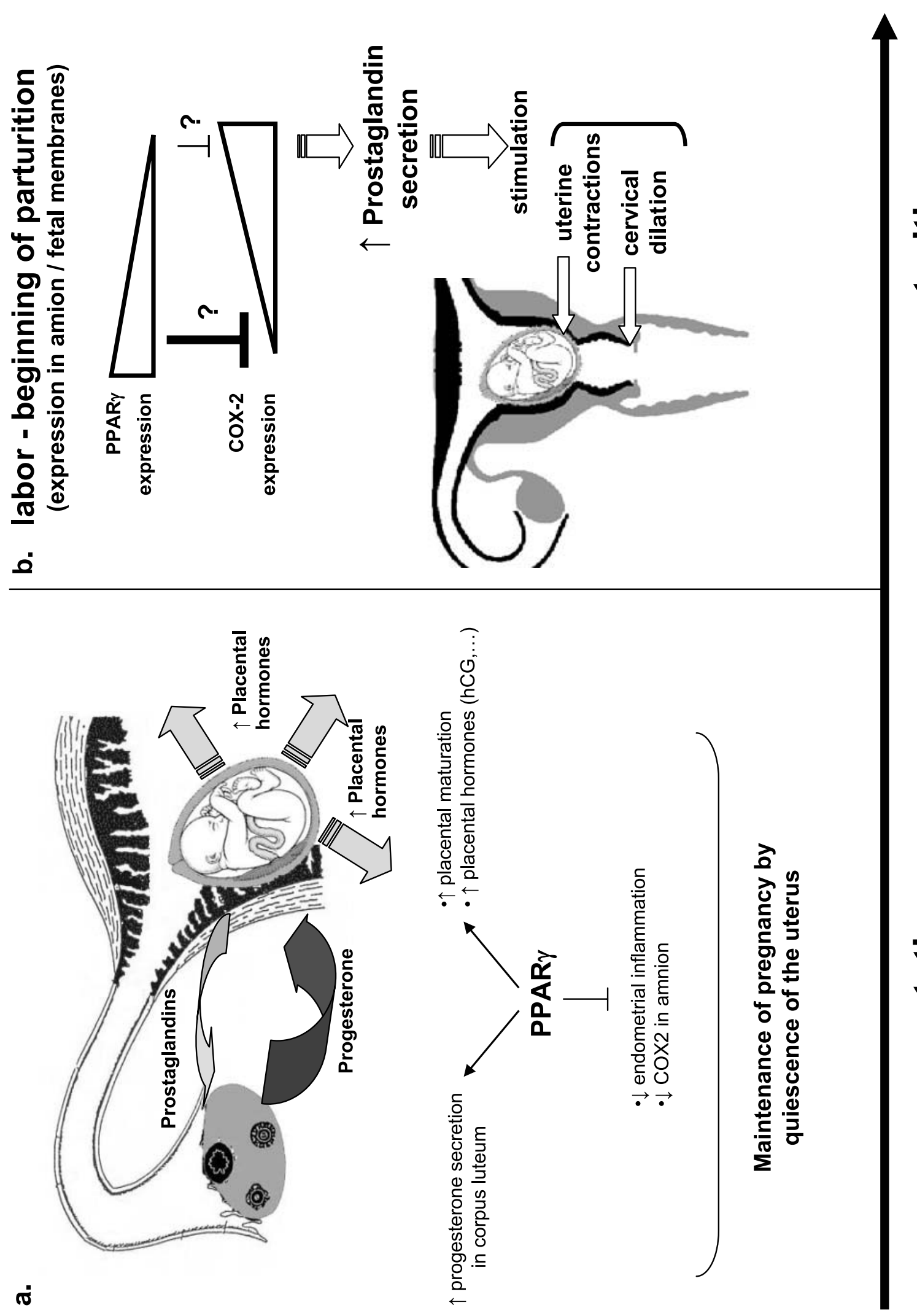
esters to female rats leads to an increase in the length of the estrous cycle and dysovulation (Davis et al. 1994).

Limited experiments have shown that phthalate esters may interfere with reproduction by interacting with PPARs. PPAR $\alpha$ and PPAR $\gamma$ are responsive to DEHP in vitro and are translocated to the nucleus in primary Sertoli cells after the incubation of these cells with phthalate esters (Dufour et al. 2003, Bhattacharya et al. 2005). Lovekamp-Swan et al. suggested that phthalates activate both PPAR $\alpha$ and PPAR $\gamma$ in cultured rat granulosa cells, resulting in the complete inhibition of aromatase (Lovekamp-Swan et al. 2003). However, only a few studies in PPAR $\alpha$-null mice have suggested that some of the effects of DEHP on fertility are mediated by PPAR $\alpha$ (Peters et al. 1997, Ward et al. 1998, Gazouli et al. 2002). The administration of DEHP resulted in milder testis lesions and higher testosterone levels in PPAR $\alpha$-null mice than in wild-type mice (Gazouli et al. 2002).

\section{The placental effects of PPARs are important for embryonic development (Fig. 3)}

$\operatorname{PPAR} \gamma$ is required for the attachment of embryos to the endometrium and the development and function of the placenta (Barak et al. 1999). Strong PPAR $\gamma$ expression has been detected in the trophectoderm and inner-cell mass of the blastocyst (Mohan et al. 2002). PPAR $\gamma$ inactivation leads to impaired placental vascularization, resulting in the death of the embryo. Pregnancy failure can be prevented by replacing PPAR $\gamma$-deficient placental cells with wildtype cells (Barak et al. 1999, Kubota et al. 1999). Similar abnormalities in placental development have been observed in $\mathrm{RXR} \alpha^{-1-}$ mice, suggesting that the $\operatorname{PPAR} \gamma-\operatorname{RXR} \alpha$ heterodimer is required for placentation (Wendling et al. 1999).

$\operatorname{PPAR} \alpha, \operatorname{PPAR} \beta / \delta$ and $\operatorname{PPAR} \gamma$ are also expressed in gestational tissues (in the amnion, choriodecidua, and placenta) (Berry et al. 2003). $\operatorname{PPAR} \beta / \delta$ is strongly expressed during decidualization, and regulates embryo implantation (Lim \& Dey 2000, 2002). PPAR $\beta / \delta$ is found around implantation sites, and $\operatorname{PPAR} \beta / \delta$-null mice present placental malformations leading to embryo death during early pregnancy (Barak et al. 2002). Prostaglandins are signaling molecules expressed during pregnancy and involved in uterine contraction during parturition. Prostaglandin $\mathrm{D}_{2}\left(\mathrm{PGD}_{2}\right)$, a major prostaglandin produced by the uterus during pregnancy, could be converted in vivo into a natural ligand of $\operatorname{PPAR} \gamma, 15 \mathrm{~d}-\mathrm{PGJ}_{2}$ (Hirata et al. 1988), but its biologic role remains to be demonstrated in vivo. Of note, $15 \mathrm{~d}-\mathrm{PGJ}_{2}$ and PPAR $\gamma$ are colocalized in trophoblast cells in rat (Asami-Miyagishi et al. 2004).

Arachidonic acid derivatives (hydroxyeicosatetraenoic acids), also ligands of PPAR $\gamma$ (Huang et al. 1999), are produced by epithelial cells of the uterus during implantation (Li et al. 2004). Inhibition of 12/15-lipoxygenase, an enzyme involved in the production of these metabolites, dramatically reduces the implantation rate ( $\mathrm{Li}$ et al. 2004). The administration of rosiglitazone overcomes this inhibition and restores the implantation rate ( $\mathrm{Li}$ et al. 2004). Another study has shown that short-term TZD administration (2 days) to pregnant wild-type rats during trophoblast differentiation decreases fetal mortality by $50 \%$ (Asami-Miyagishi et al. 2004) (Fig. 3a).

A recent study, using a model of endometriosis in rats, showed that 4 weeks of ciglitazone treatment decreased the size of endometrial explants (Lebovic et al. 2004). These findings suggest that PPAR $\gamma$ is involved in the attachment of embryos during pregnancy. In addition, during parturition, the production of prostaglandins by the endometrium, myometrium and fetal membranes increases, inducing contractions of the myometrium during labor. Cyclooxygenase-2 (COX-2) catalyzes prostaglandin production and is downregulated by $\operatorname{PPAR} \gamma$ (Subbaramaiah et al. 2001). At the start of parturition, PPAR $\gamma$ expression decreases and COX-2 production increases slightly in fetal membranes, suggesting that PPAR $\gamma$ promotes quiescence of the uterus, favoring gestation (Dunn-Albanese et al. 2004, Ackerman et al. 2005) (Fig. 3b).

Finally, in man, PPAR $\gamma$ is also expressed in the placenta (cytotrophoblasts and syncytiotrophoblasts). Its activation stimulates the production and secretion of hormones required during pregnancy and fetal development, including human choriogonadotropins and syncytiotrophoblast hormones (human placental growth hormone and leptin) (Tarrade et al. 2001). Thus, PPAR $\gamma$ is essential for the maturation of a functional placenta (Fig. 3).

\section{Conclusion}

These recent experiments raise several questions. The first concerns the natural ligands of PPAR $\gamma$ in different tissues and, more precisely, in reproductive tissues expressing this receptor. $\operatorname{PPAR} \gamma$ may play a key role in linking lipid metabolism and reproduction in general. It would be of interest to investigate the impact of different types of fatty acid, integrated into food, on ovulation capacity and fetal development. Another important question is whether the positive effects obtained with TZDs in PCOS patients are due to a direct effect on the ovaries or a positive effect on glucose homeostasis. Additional experiments are now required to increase our knowledge of the way in which lipid metabolism influences reproductive function.

\section{Acknowledgements}

The authors thank A Edelman and J Sappa for expert language revision. The authors declare that there is no conflict of interest that would prejudice the impartiality of this scientific work. 


\section{References}

Ackerman WE 4th, Zhang XL, Rovin BH \& Kniss DA 2005 Modulation of cytokine-induced cyclooxygenase 2 expression by PPARG ligands through NFKB signal disruption in human WISH and amnion cells. Biology of Reproduction 73 527-535.

Asami-Miyagishi R, Iseki S, Usui M, Uchida K, Kubo H \& Morita I 2004 Expression and function of PPARgamma in rat placental development. Biochemical and Biophysical Research Communications 315 497-501.

Bamba H, Ota S, Kato A, Kawamoto C \& Fujiwara K 2000 Prostaglandins up-regulate vascular endothelial growth factor production through distinct pathways in differentiated U937 cells. Biochemical and Biophysical Research Communications 273 485-491.

Banerjee J \& Komar CM 2006 Effects of luteinizing hormone on peroxisome proliferator-activated receptor $\gamma$ in the rat ovary before and after the gonadotropin surge. Reproduction 131 93-101.

Barak Y, Nelson MC, Ong ES, Jones YZ, Ruiz-Lozano P, Chien KR, Koder A \& Evans RM 1999 PPAR gamma is required for placental, cardiac, and adipose tissue development. Molecular Cell $4585-595$.

Barak Y, Liao D, He W, Ong ES, Nelson MC, Olefsky JM, Boland R \& Evans RM 2002 Effects of peroxisome proliferator-activated receptor delta on placentation, adiposity, and colorectal cancer. PNAS 99 303-308.

Berry EB, Eykholt R, Helliwell RJ, Gilmour RS, Mitchell MD \& Marvin KW 2003 Peroxisome proliferator-activated receptor isoform expression changes in human gestational tissues with labor at term. Molecular Pharmacology 64 1586-1590.

Bhattacharya N, Dufour JM, Vo MN, Okita J, Okita R \& Kim KH 2005 Differential effects of phthalates on the testis and the liver. Biology of Reproduction 72 745-754.

Bjorntorp P 1996 The regulation of adipose tissue distribution in humans. International Journal of Obesity and Related Metabolic Disorders 20 291-302.

Braissant O, Foufelle F, Scotto C, Dauca M \& Wahli W 1996 Differential expression of peroxisome proliferator-activated receptors (PPARs): tissue distribution of PPAR-alpha, -beta, and -gamma in the adult rat. Endocrinology 137 354-366.

Brettenthaler N, De Geyter C, Huber PR \& Keller U 2004 Effect of the insulin sensitizer pioglitazone on insulin resistance, hyperandrogenism, and ovulatory dysfunction in women with polycystic ovary syndrome. Journal of Clinical Endocrinology and Metabolism 89 3835-3840.

Bruning JC, Gautam D, Burks DJ, Gillette J, Schubert M, Orban PC, Klein R, Krone W, Muller-Wieland D \& Kahn CR 2000 Role of brain insulin receptor in control of body weight and reproduction. Science $2892122-2125$.

Burks DJ, Font de Mora J, Schubert M, Withers DJ, Myers MG, Towery HH, Altamuro SL, Flint CL \& White MF 2000 IRS-2 pathways integrate female reproduction and energy homeostasis. Nature 407 377-382.

Corton JC \& Lapinskas PJ 2005 Peroxisome proliferator-activated receptors: mediators of phthalate ester-induced effects in the male reproductive tract? Toxicological Sciences 83 4-17.

Cui Y, Miyoshi K, Claudio E, Siebenlist UK, Gonzalez FJ, Flaws J, Wagner KU \& Hennighausen L 2002 Loss of the peroxisome proliferation-activated receptor gamma (PPARgamma) does not affect mammary development and propensity for tumor formation but leads to reduced fertility. Journal of Biological Chemistry 277 17830-17835.

Davis BJ, Maronpot RR \& Heindel JJ 1994 Di-(2-ethylhexyl) phthalate suppresses estradiol and ovulation in cycling rats. Toxicology and Applied Pharmacology 128 216-223.

Debril MB, Renaud JP, Fajas L \& Auwerx J 2001 The pleiotropic functions of peroxisome proliferator-activated receptor gamma. Journal of Molecular Medicine 79 30-47.
Deneux C \& Kuttenn F 1998 Hyperandrogenism and fertility. Annales d'endocrinologie 59 311-318.

Desvergne B \& Wahli W 1999 Peroxisome proliferator-activated receptors: nuclear control of metabolism. Endocrine Reviews 20 649-688.

Douard V, Hermier D, Magistrini M \& Blesbois E 2003 Reproductive period affects lipid composition and quality of fresh and stored spermatozoa in turkeys. Theriogenology 59 753-764.

Dufour JM, Vo MN, Bhattacharya N, Okita J, Okita R \& Kim KH 2003 Peroxisome proliferators disrupt retinoic acid receptor alpha signaling in the testis. Biology of Reproduction 68 1215-1224.

Dunaif A 1997 Insulin resistance and the polycystic ovary syndrome: mechanism and implications for pathogenesis. Endocrine Reviews $18774-800$.

Dunaif A 1999 Insulin action in the polycystic ovary syndrome. Endocrinology and Metabolism Clinics of North America 28 341-359.

Dunaif A, Scott D, Finegood D, Quintana B \& Whitcomb R 1996 The insulin-sensitizing agent troglitazone improves metabolic and reproductive abnormalities in the polycystic ovary syndrome. Journal of Clinical Endocrinology and Metabolism 81 3299-3306.

Dunn-Albanese LR, Ackerman WE 4th, Xie Y, Iams JD \& Kniss DA 2004 Reciprocal expression of peroxisome proliferator-activated receptor-gamma and cyclooxygenase-2 in human term parturition. American Journal of Obstetrics and Gynecology 190 809-816.

Duran-Sandoval D, Thomas AC, Bailleul B, Fruchart JC \& Staels B 2003 Pharmacology of PPARalpha, PPARgamma and dual PPARalpha/gamma agonists in clinical development Médecine sciences 19 819-825.

Elbrecht A, Chen Y, Cullinan CA, Hayes N, Leibowitz M, Moller DE \& Berger J 1996 Molecular cloning, expression and characterization of human peroxisome proliferator activated receptors gamma 1 and gamma 2. Biochemical and Biophysical Research Communications 224 431-437.

Fan W, Yanase T, Morinaga H, Mu YM, Nomura M, Okabe T, Goto K, Harada N \& Nawata H 2005 Activation of peroxisome proliferator-activated receptor-gamma and retinoid $\mathrm{X}$ receptor inhibits aromatase transcription via nuclear factor-kappaB. Endocrinology 146 85-92.

Fraser HM, Dickson SE, Lunn SF, Wulff C, Morris KD, Carroll V \& Bicknell R 2000 Suppression of luteal angiogenesis in the primate after neutralization of vascular endothelial growth factor. Endocrinology 141 995-1000.

Froment P, Holzenberger M \& Monget P 2001 Insuline, métabolisme énergétique et fertilité. Médecine sciences 17 817-818.

Froment P, Fabre S, Dupont J, Pisselet C, Chesneau D, Staels B \& Monget P 2003 Expression and functional role of peroxisome proliferator-activated receptor-gamma in ovarian folliculogenesis in the sheep. Biology of Reproduction 69 1665-1674.

Gasic S, Bodenburg Y, Nagamani M, Green A \& Urban RJ 1998 Troglitazone inhibits progesterone production in porcine granulosa cells. Endocrinology 139 4962-4966.

Gasic S, Nagamani M, Green A \& Urban RJ 2001 Troglitazone is a competitive inhibitor of 3 beta-hydroxysteroid dehydrogenase enzyme in the ovary. American Journal of Obstetrics and Gynecology $184575-579$.

Gazouli M, Yao ZX, Boujrad N, Corton JC, Culty M \& Papadopoulos V 2002 Effect of peroxisome proliferators on Leydig cell peripheral-type benzodiazepine receptor gene expression, hormone-stimulated cholesterol transport, and steroidogenesis: role of the peroxisome proliferator-activator receptor alpha. Endocrinology 143 2571-2583.

Gurnell M, Savage DB, Chatterjee VK \& O'Rahilly S 2003 The metabolic syndrome: peroxisome proliferator-activated receptor gamma and its therapeutic modulation. Journal of Clinical Endocrinology and Metabolism 88 2412-2421.

Hase T, Yoshimura R, Mitsuhashi M, Segawa Y, Kawahito Y, Wada S, Nakatani T \& Sano H 2002 Expression of peroxisome 
proliferator-activated receptors in human testicular cancer and growth inhibition by its agonists. Urology 60 542-547.

Heaney AP, Fernando M \& Melmed S 2003 PPAR-gamma receptor ligands: novel therapy for pituitary adenomas. Journal of Clinical Investigation 111 1381-1388.

Hirata Y, Hayashi H, Ito S, Kikawa Y, Ishibashi M, Sudo M, Miyazaki H, Fukushima M, Narumiya S \& Hayaishi O 1988 Occurrence of 9-deoxy-delta 9, delta 12-13,14-dihydroprostaglandin $\mathrm{D}_{2}$ in human urine. Journal of Biological Chemistry 263 16619-16625.

Holte J, Bergh T, Berne C \& Lithell H 1994 Serum lipoprotein lipid profile in women with the polycystic ovary syndrome: relation to anthropometric, endocrine and metabolic variables. Clinical Endocrinology 41 463-471.

Houseknecht KL, Cole BM \& Steele PJ 2002 Peroxisome proliferator-activated receptor gamma (PPARgamma) and its ligands: a review. Domestic Animal Endocrinology 22 1-23.

Huang JT, Welch JS, Ricote M, Binder CJ, Willson TM, Kelly C, Witztum JL, Funk CD, Conrad D \& Glass CK 1999 Interleukin-4-dependent production of PPAR-gamma ligands in macrophages by 12/15-lipoxygenase. Nature 400 378-382.

Issemann I \& Green S 1990 Activation of a member of the steroid hormone receptor superfamily by peroxisome proliferators. Nature 347 645-650.

Iuorno MJ \& Nestler JE 2001 Insulin-lowering drugs in polycystic ovary syndrome. Obstetrics and Gynecology Clinics of North America 28 153-164.

Jablonka-Shariff A, Ravi S, Beltsos AN, Murphy LL \& Olson LM 1999 Abnormal estrous cyclicity after disruption of endothelial and inducible nitric oxide synthase in mice. Biology of Reproduction 61 171-177.

Jonard S \& Dewailly D 2002 Polycystic ovary syndrome: recent genetic contributions. Gynécologie, obstétrique \& fertilité 30 603-609.

Kaczmarek MM, Schams D \& Ziecik AJ 2005 Role of vascular endothelial growth factor in ovarian physiology - an overview. Reproductive Biology 5 111-136.

Kapoor D, Goodwin E, Channer KS \& Jones TH 2005 Rosiglitazone increases testosterone levels and reduces waist hip ratio in hypogonadal men with type 2 diabetes. Endocrine Society 87 th Annual Meeting. San Diego Convention Center, San Diego, USA.

Kato K, Satoh H, Endo Y, Yamada D, Midorikawa S, Sato W, Mizuno K, Fujita T, Tsukamoto K \& Watanabe T 1999 Thiazolidinediones down-regulate plasminogen activator inhibitor type 1 expression in human vascular endothelial cells: a possible role for PPARgamma in endothelial function. Biochemical and Biophysical Research Communications 258 431-435.

Komar C 2005 Initiation of peroxysome proliferator-activated receptor gamma (PPARg) expression in the neonatal rat ovary. Society for the Study of Reproduction $38^{\text {th }}$ Annual Meeting. Quebec City, Quebec, Canada.

Komar CM, Braissant O, Wahli W \& Curry TE Jr 2001 Expression and localization of PPARs in the rat ovary during follicular development and the periovulatory period. Endocrinology 142 4831-4838.

Kubota N, Terauchi Y, Miki H, Tamemoto H, Yamauchi T, Komeda K, Satoh S, Nakano R, Ishii C, Sugiyama T et al. 1999 PPAR gamma mediates high-fat diet-induced adipocyte hypertrophy and insulin resistance. Molecular Cell 4 597-609.

La Marca A, Egbe TO, Morgante G, Paglia T, Cianci A \& De Leo V 2000 Metformin treatment reduces ovarian cytochrome P-450c17 alpha response to human chorionic gonadotrophin in women with insulin resistance-related polycystic ovary syndrome. Human Reproduction 15 21-23.

Larsen TM, Toubro S \& Astrup A 2003 PPARgamma agonists in the treatment of type II diabetes: is increased fatness commensurate with long-term efficacy? International Journal of Obesity and Related Metabolic Disorders 27 147-161.
Lebovic DI, Kir M \& Casey CL 2004 Peroxisome proliferatoractivated receptor-gamma induces regression of endometrial explants in a rat model of endometriosis. Fertility and Sterility 82 Suppl 3 1008-1013.

Lee SS, Pineau T, Drago J, Lee EJ, Owens JW, Kroetz DL, Fernandez-Salguero PM, Westphal H \& Gonzalez FJ 1995 Targeted disruption of the alpha isoform of the peroxisome proliferatoractivated receptor gene in mice results in abolishment of the pleiotropic effects of peroxisome proliferators. Molecular and Cellular Biology 15 3012-3022.

Lehmann JM, Moore LB, Smith-Oliver TA, Wilkison WO, Willson TM \& Kliewer SA 1995 An antidiabetic thiazolidinedione is a high affinity ligand for peroxisome proliferator-activated receptor gamma (PPAR gamma). Journal of Biological Chemistry 270 12953-12956.

Li Q, Cheon YP, Kannan A, Shanker S, Bagchi IC \& Bagchi MK 2004 A novel pathway involving progesterone receptor, 12/15-lipoxygenase-derived eicosanoids, and peroxisome proliferator-activated receptor gamma regulates implantation in mice. Journal of Biological Chemistry 279 11570-11581.

Lim H \& Dey SK 2000 PPAR delta functions as a prostacyclin receptor in blastocyst implantation. Trends in Endocrinology and Metabolism 11 137-142.

Lim H \& Dey SK 2002 A novel pathway of prostacyclin signaling-hanging out with nuclear receptors. Endocrinology 143 3207-3210.

Lim H, Paria BC, Das SK, Dinchuk JE, Langenbach R, Trzaskos JM \& Dey SK 1997 Multiple female reproductive failures in cyclooxygenase 2-deficient mice. Cell 91 197-208.

Lohrke B, Viergutz T, Shahi SK, Pohland R, Wollenhaupt K, Goldammer T, Walzel H \& Kanitz W 1998 Detection and functional characterisation of the transcription factor peroxisome proliferator-activated receptor gamma in lutein cells. Journal of Endocrinology 159 429-439.

Lovekamp-Swan T \& Chaffin CL 2005 The peroxisome proliferatoractivated receptor gamma ligand troglitazone induces apoptosis and 553 in rat granulosa cells. Molecular and Cellular Endocrinology 233 15-24.

Lovekamp-Swan T, Jetten AM \& Davis BJ 2003 Dual activation of PPARalpha and PPARgamma by mono-(2-ethylhexyl) phthalate in rat ovarian granulosa cells. Molecular and Cellular Endocrinology 201 133-141.

Marshall JC \& Eagleson CA 1999 Neuroendocrine aspects of polycystic ovary syndrome. Endocrinology and Metabolism Clinics of North America 28 295-324.

Mendez M \& LaPointe 2003 MC PPARgamma inhibition of cyclooxygenase-2, $\mathrm{PGE}_{2}$ synthase, and inducible nitric oxide synthase in cardiac myocytes. Hypertension 42 844-850.

Minge CE, Ryan NK, Hoek KH, Robker RL \& Norman RJ 2006 Troglitazone regulates peroxisome proliferator-activated receptors and inducible nitric oxide synthase in murine ovarian macrophages. Biology of Reproduction 74 153-160.

Mohan M, Ryder S, Claypool PL, Geisert RD \& Malayer JR 2002 Analysis of gene expression in the bovine blastocyst produced in vitro using suppression-subtractive hybridization. Biology of Reproduction 67 447-453.

Mouihate A, Boisse L \& Pittman QJ 2004 A novel antipyretic action of 15-deoxy-delta12,14-prostaglandin $\mathrm{J}_{2}$ in the rat brain. Journal of Neuroscience 24 1312-1308.

Mu YM, Yanase T, Nishi Y, Waseda N, Oda T, Tanaka A, Takayanagi R \& Nawata H 2000 Insulin sensitizer, troglitazone, directly inhibits aromatase activity in human ovarian granulosa cells. Biochemical and Biophysical Research Communications 271 710-713.

Musi N, Hirshman MF, Nygren J, Svanfeldt M, Bavenholm P, Rooyackers O, Zhou G, Williamson JM, Ljunqvist O, Efendic S et al. 2002 Metformin increases AMP-activated protein kinase activity in skeletal muscle of subjects with type 2 diabetes. Diabetes 51 2074-2081. 
Mylchreest E, Cattley RC \& Foster PM 1998 Male reproductive tract malformations in rats following gestational and lactational exposure to Di(n-butyl)phthalate: an antiandrogenic mechanism? Toxicological Sciences 43 47-60.

Nestler JE, Jakubowicz DJ, Reamer P, Gunn RD \& Allan G 1999 Ovulatory and metabolic effects of D-chiro-inositol in the polycystic ovary syndrome. New England Journal of Medicine 340 1314-1320.

Nogueiras R, Barreiro ML, Caminos JE, Gaytan F, Suominen JS, Navarro VM, Casanueva FF, Aguilar E, Toppari J, Dieguez C et al. 2004 Novel expression of resistin in rat testis: functional role and regulation by nutritional status and hormonal factors. Journal of Cell Science 117 3247-3257.

Patel SM, Szapary P, Ratcliffe SJ, Wolfe ML \& Cappola AR 2005 The effect of pioglitazone on insulin sensitivity and androgen levels in non-diabetic patients with the metabolic syndrome: a double-blind, randomized, placebo-controlled dose escalation trial. Endocrine Society 87th Annual Meeting San Diego Convention Center, San Diego, CA, USA.

Peters JM, Taubeneck MW, Keen CL \& Gonzalez FJ 1997 Di(2-ethylhexyl) phthalate induces a functional zinc deficiency during pregnancy and teratogenesis that is independent of peroxisome proliferator-activated receptor-alpha. Teratology 56 311-316.

Peters JM, Lee SS, Li W, Ward JM, Gavrilova O, Everett C, Reitman ML, Hudson LD \& Gonzalez FJ 2000 Growth, adipose, brain, and skin alterations resulting from targeted disruption of the mouse peroxisome proliferator-activated receptor beta(delta). Molecular and Cellular Biology 20 5119-5128.

Picard F \& Auwerx J 2002 PPAR (gamma) and glucose homeostasis. Annual Review of Nutrition 22 167-197.

Pitteloud N, Hardin M, Dwyer AA, Valassi E, Yialamas M, Elahi D \& Hayes FJ 2005 Increasing insulin resistance is associated with a decrease in Leydig cell testosterone secretion in men. Journal of Clinical Endocrinology and Metabolism 90 2636-2641.

Poretsky L, Cataldo NA, Rosenwaks Z \& Giudice LC 1999 The insulin-related ovarian regulatory system in health and disease. Endocrine Reviews 20 535-582.

Risma KA, Clay CM, Nett TM, Wagner T, Yun J \& Nilson JH 1995 Targeted overexpression of luteinizing hormone in transgenic mice leads to infertility, polycystic ovaries, and ovarian tumors. PNAS 92 1322-1326.

Rosenfield RL 1999 Ovarian and adrenal function in polycystic ovary syndrome. Endocrinology and Metabolism Clinics of North America 28 265-293.

Sato K, Fukao K, Seki Y \& Akiba Y 2004 Expression of the chicken peroxisome proliferator-activated receptor-gamma gene is influenced by aging, nutrition, and agonist administration. Poultry Science 83 1342-1347.

Schoppee PD, Garmey JC \& Veldhuis JD 2002 Putative activation of the peroxisome proliferator-activated receptor gamma impairs androgen and enhances progesterone biosynthesis in primary cultures of porcine theca cells. Biology of Reproduction 66 190-198.

Schultz R, Yan W, Toppari J, Volkl A, Gustafsson JA \& Pelto-Huikko M 1999 Expression of peroxisome proliferatoractivated receptor alpha messenger ribonucleic acid and protein in human and rat testis. Endocrinology 140 2968-2975.

Seli E \& Duleba AJ 2004 Treatment of PCOS with metformin and other insulin-sensitizing agents. Current Diabetes Reports 4 69-75.

Seto-Young D, Paliou M, Schlosser J, Avtanski D, Park A, Patel P, Holcomb K, Chang P \& Poretsky L 2005 Direct thiazolidinedione action in the human ovary: insulin-independent and insulin-sensitizing effects on steroidogenesis and insulin-like growth factor binding protein-1 production. Journal of Clinical Endocrinology and Metabolism 90 6099-6105.
Shu H, Wong B, Zhou G, Li Y, Berger J, Woods JW, Wright SD \& Cai TQ 2000 Activation of PPARalpha or gamma reduces secretion of matrix metalloproteinase 9 but not interleukin 8 from human monocytic THP-1 cells. Biochemical and Biophysical Research Communications 267 345-349.

Sorensen HN, Treuter E \& Gustafsson JA 1998 Regulation of peroxisome proliferator-activated receptors. Vitamins and Hormones 54 121-166.

Staels B \& Fruchart JC 2005 Therapeutic roles of peroxisome proliferator-activated receptor agonists. Diabetes 54 2460-2470.

Subbaramaiah K, Lin DT, Hart JC \& Dannenberg AJ 2001 Peroxisome proliferator-activated receptor gamma ligands suppress the transcriptional activation of cyclooxygenase-2. Evidence for involvement of activator protein-1 and CREB-binding protein/p300. Journal of Biological Chemistry 276 12440-12448.

Tarrade A, Schoonjans K, Guibourdenche J, Bidart JM, Vidaud M, Auwerx J, Rochette-Egly C \& Evain-Brion D 2001 PPAR gamma/ RXR alpha heterodimers are involved in human CG beta synthesis and human trophoblast differentiation. Endocrinology 142 4504-4514.

Thomas K, Sung DY, Chen X, Gibbs R, McCarrey J \& Walker W 2005 Developmental patterns of PPAR/RXR gene expression during spermatogenesis. Society for the Study of Reproduction $38^{\text {th }}$ Annual Meeting Quebec City, Quebec, Canada.

Thompson CJ, Ross SM, Hensley J, Liu K, Heinze SC, Young SS \& Gaido KW 2005 Differential steroidogenic gene expression in the fetal adrenal gland versus the testis and rapid and dynamic response of the fetal testis to Di(n-butyl) phthalate. Biology of Reproduction 73 908-917.

Tosca L, Froment P, Solnais P, Ferre P, Foufelle F \& Dupont J 2005 Adenosine $5^{\prime}$-monophosphate-activated protein kinase regulates progesterone secretion in rat granulosa cells. Endocrinology $1464500-4513$

Viergutz T, Loehrke B, Poehland R, Becker F \& Kanitz W 2000 Relationship between different stages of the corpus luteum and the expression of the peroxisome proliferator-activated receptor gamma protein in bovine large lutein cells. Journal of Reproduction and Fertility 118 153-161.

Ward JM, Peters JM, Perella CM \& Gonzalez FJ 1998 Receptor and nonreceptor-mediated organ-specific toxicity of di(2-ethylhexyl) phthalate (DEHP) in peroxisome proliferator-activated receptor alpha-null mice. Toxicologic Pathology 26 240-246.

Wendling O, Chambon P \& Mark M 1999 Retinoid X receptors are essential for early mouse development and placentogenesis. PNAS $96547-551$.

Wiesner G, Morash BA, Ur E \& Wilkinson M 2004 Food restriction regulates adipose-specific cytokines in pituitary gland but not in hypothalamus. Journal of Endocrinology 180 R1-6.

Xin X, Yang S, Kowalski J \& Gerritsen ME 1999 Peroxisome proliferator-activated receptor gamma ligands are potent inhibitors of angiogenesis in vitro and in vivo. Journal of Biological Chemistry 274 9116-9121.

Yamakawa K, Hosoi M, Koyama H, Tanaka S, Fukumoto S, Morii H \& Nishizawa Y 2000 Peroxisome proliferator-activated receptor-gamma agonists increase vascular endothelial growth factor expression in human vascular smooth muscle cells. Biochemical and Biophysical Research Communications 271 571-574.

Zhou G, Myers R, Li Y, Chen Y, Shen X, Fenyk-Melody J, Wu M, Ventre J, Doebber T, Fujii N et al. 2001 Role of AMP-activated protein kinase in mechanism of metformin action. Journal of Clinical Investigation 108 1167-1174.

Received in final form 30 January 2006

Accepted 27 February 2006

Made available online as an Accepted Preprint

13 March 2006 